\author{
М.Ф. Пічугін ${ }^{1}$, Д.А. Іщенко ${ }^{2}$, В.А. Кирилюк ${ }^{2}$, Я.М. Кожушко ${ }^{1}$ \\ ${ }^{1}$ Харківський начіональний університет Повітряних Сил ім. I. Кожедуба, Харків \\ ${ }^{2}$ Житомирський військовий інститут ім. С.П. Корольова, Житомир
}

\title{
ПОБУДОВА СПЕЦІАЛІЗОВАНОГО ШАРУ ПАРАМЕТРІВ РЕЛЬЄФУ МІСЦЕВОСТІ У ГЕОІНФОРМАЦІЙНІЙ СИСТЕМІ ДЛЯ ПЛАНУВАННЯ ДІЙ РАДІОЕЛЕКТРОННИХ ЗАСОБІВ В УМОВАХ РАДІОЕЛЕКТРОННОЇ БОРОТЬБИ
}

\begin{abstract}
Запропоновано підхід до врахування впливу рельєфу місиевості на радіоелектронне подавлення приймачів радіоелектронних об'єктів різного базування за рахунок побудови спеціалізованого шару геоінформаційної системи. Підхід передбачає створення для кожної точки мапи масиву коефіцієнтів згасання при поширенні електромагнітної хвилі до будь-якої іншої точки, заданої з певною дискретністю в межах обмеженої ділянки простору. Обгрунтовано умови переважаючого впливу явищ інтерферениії та рефракиії для перевищень фізичних перешкод на трасі поширення електромагнітних хвиль. Наведено математичний апарат розрахунку радіоелектронного подавлення для формування масиву даних для спеціалізованого шару геоінформаційної системи.
\end{abstract}

Ключові слова: ефективність подавлення, множник ослаблення, інтерференція, рефракція, умови поширення електромагнітних хвиль, геоінформаційна система, радіоелектронний засіб.

\section{Вступ}

Постановка проблеми. В умовах сучасних бойових дій за великої кількості радіоелектронних об’єктів і радіоелектронних засобів (РЕЗ) наземного та повітряно-космічного базування [1-4], оцінювання можливостей 3 радіоелектронного подавлення (РЕП) може здійснюватись лише заздалегідь та для фіксованих варіантів розташування РЕ3 та засобів радіоелектронної боротьби (РЕБ). Це пояснюється особливостями планування дій з застосуванням РЕ3 (зв'язку, радіолокаційних, розвідки, радіоелектронного подавлення тощо) в умовах радіоелектронної боротьби (РЕБ). Планування застосування РЕЗ в умовах РЕБ у більшості випадків потребує прогнозування відношення сигнал/перешкода на входах приймачів, які подавляються, за розрахунками, що проводяться в умовах невизначеності за їх невідомого положення. Ця потреба, а також обов'язковість врахування умов поширення електромагнітних хвиль, обумовлюють необхідність оцінювання відношення перешкода/сигнал для кожної точки значної просторової області (включаючи побудову профілю рельєфу до кожної точки та визначення множника ослаблення при інтерференції та рефракції), а отже великих обчислювальних витрат. Використання елементів геоінформаційних систем (ГІС) при плануванні застосування радіоелектронних засобів (РЕ3) супроводжується проблемою вирішення протиріччя між детальністю шару висот ГІС, обсягом обчислювальних витрат та точністю моделей впливу рельєфу на поширення електромагнітних хвиль.

Оперативне реагування на зміну радіоелектронної обстановки вбачається досить складним. Для зменшення об'єму обчислювальних витрат необхідно виділити складову, яка описує умови розповсюдження електромагнітних хвиль, та оцінити можливість та доцільність створення відповідного інформаційного шару ГІС.

Планування дій 3 застосуванням радіоелектронних засобів (зв'язку, радіолокаційних, розвідки, радіоелектронного подавлення тощо) в умовах радіоелектронної боротьби (РЕБ) у більшості випадків потребує прогнозування відношення сигнал/перешкода на входах приймачів, які подавляються, за розрахунками, що проводяться в умовах невизначеності за їх невідомого положення. Ця потреба, а також обов'язковість врахування умов поширення електромагнітних хвиль, обумовлюють необхідність оцінювання відношення перешкода/сигнал для кожної точки значної просторової області (включаючи побудову профілю рельєфу до кожної точки та визначення множника ослаблення при інтерференції та рефракції), а отже великих обчислювальних витрат. Використання елементів геоінформаційних систем (ГІС) при плануванні застосування радіоелектронних засобів (РЕ3) стало вже традиційним. При цьому виникає проблема вирішення протиріччя між детальністю шару висот ГІС, обсягом обчислювальних витрат та точністю моделей впливу рельєфу на поширення електромагнітних хвиль.

Слід відмітити, що реалізація різноманітних спеціалізованих шарів даних у складі ГІС спеціального призначення на протязі тривалого часу вже використовується у збройних силах країн-членів НАТО [5] та тривалий час є стандартом [6], що має вигляд геопросторової підтримки операцій (бойових дій) під час проведення повітряно-космічних операцій НАТО [7]. 
Аналіз останніх досліджень та публікацій. В роботах [8-10] на основі розробленої у [11] методики побудови зони подавлення системи радіозв'язку з урахуванням рельєфу місцевості, сферичності Землі та тропосферної рефракції запропоновано детальний математичний апарат, який дозволяє побудувати просторові зони подавлення для різних варіантів комбінацій “передавач”, “приймач”, “засіб перешкод”, в тому числі й за умов невизначеності. Водночас запропонований математичний апарат вимагає побудови траси розповсюдження та проведення великого об’єму розрахунків для кожної точки простору. В роботах [8-13] наведені методики, які дозволяють вирішувати окремі часткові задачі, в тому числі з використанням елементів ГІС, з урахуванням основних факторів впливу. Зокрема в [12-13] розглянуто питання оптимізації розміщення радіоелектронних засобів на місцевості, а в [14-17] - питання проектування радіоліній та частотно-територіальне планування. Водночас існує ряд завдань, які вимагають проведення розрахунків, пов'язаних з співвідношенням енергетики сигналів та перешкод у режимі, близькому до реального часу. За умов значної кількості радіоелектронних засобів задача може бути вирішена збільшенням часу, розпаралелюванням задач, спрощенням розрахунків або формуванням спеціалізованого шару ГІС, який враховуватиме вплив умов розповсюдження для кожної пари точок.

Отже, не вирішеним раніше завданням є розроблення математичного апарату для формування спеціалізованого шару ГІС параметрів впливу умов поширення електромагнітних хвиль (рельєфу місцевості) на ефективність радіоелектронного подавлення та визначення його раціонального об'єму.

Таким чином, мета статті полягає в обгрунтуванні математичного апарату для побудови спеціалізованого шару параметрів рельєфу місцевості у геоінформаційній системі для планування дій радіоелектронних засобів в умовах радіоелектронної боротьби завдяки урахуванню параметрів впливу умов поширення електромагнітних хвиль (рельєфу місцевості) 3 подальшою метою збільшення ефективності радіоелектронного подавлення.

\section{Виклад основного матеріалу}

Відомо [18], що умовою подавлення є забезпечення потужності перешкоди $P_{n}$ вx на вході приймача в $k_{n}$ раз більшої за потужність сигналу $P_{c \text { вx }}$ :

$$
k_{n}=\frac{P_{n B x}}{P_{c B x}} .
$$

Отже, оцінка можливості подавлення радіоелектронного засобу полягає у розрахунку відношення перешкода/сигнал і порівнянні його зі значенням коефіцієнта подавлення.
Для систем зв'язку відношення потужності перешкоди до потужності сигналу в будь-якій точці простору має вигляд:

$$
\frac{P_{n . B x}}{P_{c . B x}}=\frac{P_{n} G_{n}}{P_{c} G_{c}} \cdot \frac{D_{\pi}^{2}}{D_{n p л}^{2}} \cdot \frac{g_{n \partial}^{2}\left(\phi_{n n}\right)}{g_{n M}^{2}\left(\phi_{n \partial}\right)} \cdot \frac{g_{n}^{2}\left(\phi_{n}\right)}{g_{c}^{2}\left(\phi_{n M}\right)} \cdot \frac{\Delta f_{n p} \gamma_{n} K_{o c}}{\Delta f_{n}}
$$

де $P_{n}$ - потужність передавача перешкод;

$G_{n}$ - коефіцієнт направленої дії антени передавача перешкод;

$\Delta f_{n}$ - ширина спектра перешкоди;

$P_{c}-$ потужність сигналу передавача системи зв'язку;

$G_{c}$ - коефіцієнт направленої дії передавальної антени;

$g_{n d}(\phi, \theta)$ - діаграма спрямованості передавальної антени по полю;

$g_{n м}(\phi, \theta)$ - діаграма спрямованості приймальної антени по полю;

$\Delta f_{n p}$ - смуга пропускання лінійної частини приймача радіолініі;

$D_{л}$ - довжина лінії (відстань між передавачем і приймачем);

$g_{n}(\phi, \theta)$ - діаграма спрямованості антени станції перешкод (по полю);

$D_{n p л}$ - відстань між джерелом перешкоди i приймачем радіолінії;

$K_{o c}$ - коефіцієнт ослаблення перешкоди;

$\gamma_{n}-$ поляризаційний коефіцієнт.

Ослаблення електромагнітних хвиль залежить від багатьох факторів, зокрема явищ інтерференції, рефракції, загасанні в дощі, тумані, пилу тощо. Коефіцієнт ослаблення може бути поданий у вигляді:

$$
K_{o c}=10^{0,1 V_{i}} 10^{0,1 V_{p}} e^{-\alpha L}
$$

де $V_{i}$ - значення множника ослаблення внаслідок інтерференції хвиль;

$V_{p}-$ значення множника ослаблення внаслідок рефракції хвиль;

$\alpha$ - коефіцієнт загасання хвиль на одиницю відстані;

$L$ - протяжність траси розповсюдження електромагнітних хвиль.

Вплив явищ інтерференції та рефракції розглядається в статті кожен окремо.

Ілюстрація геометричних параметрів, за яких розраховують такий вплив, схематично наведена на рис. 1. Значення модуля множника ослаблення при інтерференції для першого інтерференційного мінімуму визначається з виразу [19]: 


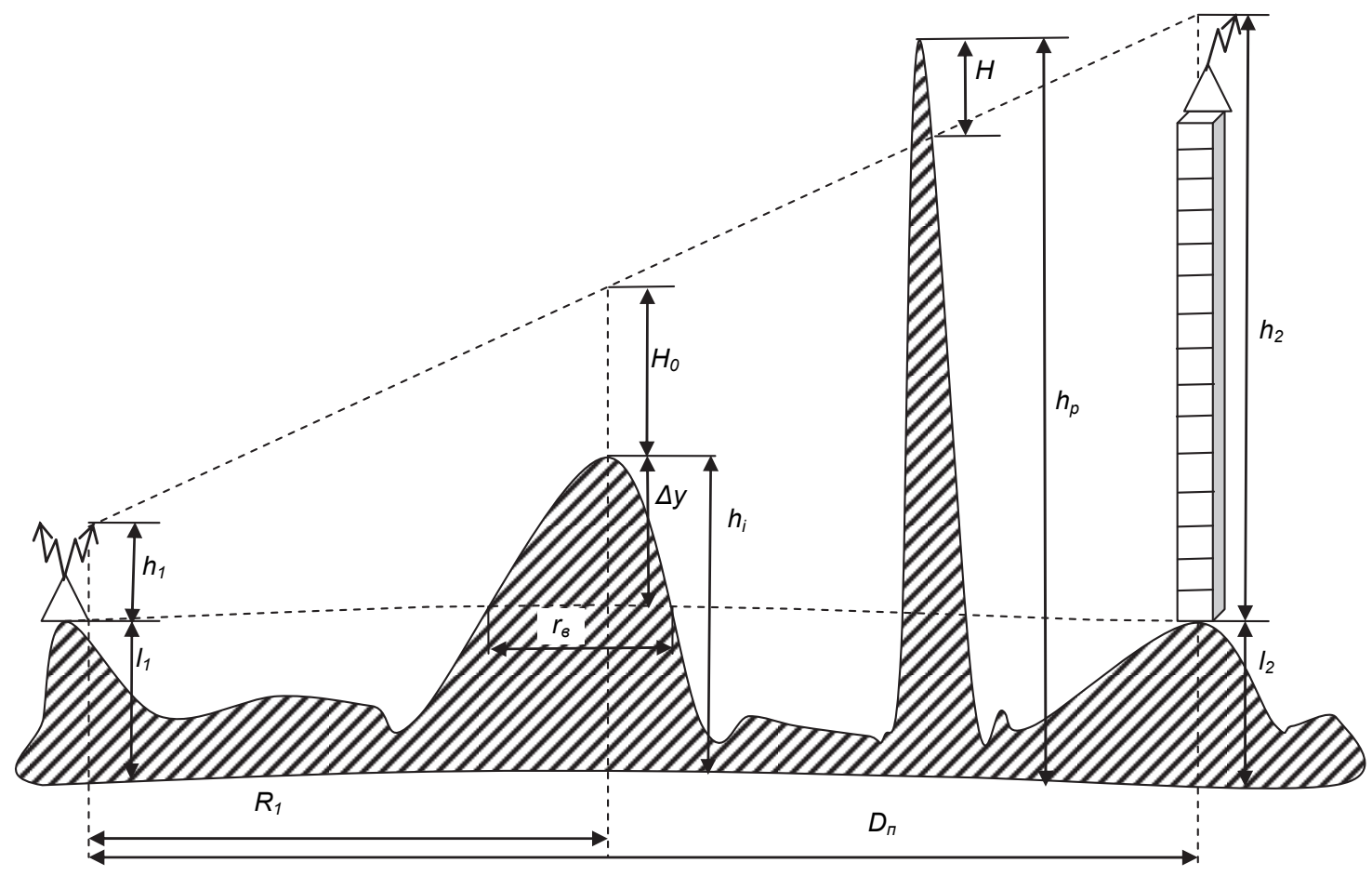

Рис. 1. Схематичне положення приймача, станції перешкод та фізичної перешкоди

$$
\left|V_{i}\right|=11,26 \frac{\Delta y \sqrt{k^{3}(1-k)^{3} D_{n}{ }^{3}}}{r_{s}^{2} \sqrt{\lambda}}=\frac{V_{i}^{*}}{\sqrt{\lambda}},
$$

де $\Delta y$ - висота перешкоди відносно лінії, що поєднує точки проекцій антен на земну поверхню;

$$
k=\frac{R_{1}}{D_{n}} \text { - відносна координата фізичної пере- }
$$

шкоди $\left(R_{1}\right.$ - відстань від передавача до фізичної перешкоди);

$$
r_{s}^{2} \text { - довжина хорди, що утворюється в ре- }
$$
зультаті перетину лінії, яка з'єднує точки проекцій антен на земну поверхню, з колом, яке апроксимує фізичну перешкоду;

$$
V_{i}^{*}=11,26 \frac{\Delta y \sqrt{k^{3}(1-k)^{3} D_{n}{ }^{3}}}{r_{B}{ }^{2}} .
$$

Висоту перешкоди відносно лінії, що поєднує точки проекцій антен на земну поверхню (рис. 1), приблизно можна розрахувати з виразу:

$$
\Delta y=h_{i}-l_{1}(1-k)-l_{2} k,
$$

де $\Delta y$ - висота фізичної перешкоди відносно рівня моря;

$h_{i}$ - висота точки знаходження антени станції перешкод відносно рівня моря;

$l_{1}$ - висота відносно рівня моря антени передавача; $l_{2}$ - висота відносно рівня моря антени приймача.

Значення модуля множника ослаблення при рефракції визначається з виразу [19]:

$$
\left|V_{p}\right|=\frac{0,16 \sqrt{D_{n} \lambda k(1-k)}}{H}=V_{p}^{*} \sqrt{\lambda},
$$

де $\lambda$ - довжина хвилі;

$H$ - перевищення фізичною перешкодою лінії, що з'єднує антени передавача та приймача;

$$
V_{p}^{*}=\frac{0,16 \sqrt{D_{n} k(1-k)}}{H} .
$$

Значення $H$ (рис. 2) розраховується з виразу:

$$
H=h_{p}-\left(l_{1}+h_{1}\right)(1-k)-\left(l_{2}+h_{2}\right) k,
$$

де $h_{p}$ - висота фізичної перешкоди відносно рівня моря;

$h_{1}$ - висота антени;

$h_{2}$ - висота польоту літака над поверхнею Землі.

Граничне значення висоти перешкоди над рівнем моря $h_{i 0}$, за якої $\epsilon$ істотним вплив на розповсюдження електромагнітних хвиль явища інтерференції, може бути оцінене з виразів

$$
\left\{\begin{array}{l}
\left(R_{3}+h_{i 0}\right)^{2}+R_{1}^{2}=\left(R_{3}+l_{1}+h_{1}\right)^{2} ; \\
\left(R_{3}+h_{i 0}\right)^{2}+\left(D_{n}-R_{1}\right)^{2}=\left(R_{3}+l_{2}+h_{2}\right)^{2},
\end{array}\right.
$$


де $R_{3}$ - радіус Землі;

$D_{n}-R_{1}-$ відстань від фізичної перешкоди до приймача РЕ3.

Тоді умовою істотного впливу інтерференції є:

$$
h_{i 0}<\frac{h_{1}+l_{1}+h_{2}+l_{2}}{2}-\frac{D_{n}^{2}(1-k)}{4 R_{3}} .
$$

Виходячи з рис. 1 та враховуючи вираз (5), значення просвіту $H_{0}$ можна подати у вигляді:

$$
H_{0}=\left(\Delta h_{2}-\Delta h_{1}\right) k+\Delta h_{1},
$$

де $\Delta h_{2}=h_{2}+l_{2}-h_{i}-$ перевищення антени приймача над висотою фізичної перешкоди над рівнем моря;

$\Delta h_{1}=h_{1}+l_{1}-h_{i}-$ перевищення антени передавача перешкод над висотою фізичної перешкоди над рівнем моря.

Отже, судячи 3 (10), значення просвіту визначається перевищенням антен передавача та приймача над висотою фізичної перешкоди над рівнем моря. Водночас найбільші інтерференційні мінімуми мають місце за таких умов:

$$
H_{0}=\sqrt{\frac{1}{3} D_{n} \lambda(1-k) k} .
$$

Вираз (11) свідчить про те, що створення масиву значень множника ослаблення у залежності від висоти антени передавача (приймача) обмежується досягненням значення просвіту, за якого можливі найбільші інтерференційні мінімуми.

Граничне значення висоти перешкоди над рівнем моря $h_{p 0}$, за якої $є$ істотним вплив на розповсюдження електромагнітних хвиль явища рефракції, можна отримати, якщо прирівняти вираз (6) до одиниці та розв'язати систему рівнянь (6-7).

Тоді умовою істотного впливу рефракції $є$ :

$h_{p 0}>\left(l_{1}+h_{1}\right)(1-k)+\left(l_{2}+h_{2}\right) k+0,16 \sqrt{D_{n} \lambda k(1-k)}$

Оцінювання можливості подавлення засобом радіоелектронної боротьби приймачів БРЛС або системи зв'язку в більшості випадків відбувається за їх невідомого положення. Це потребує оцінювання відношення перешкода/сигнал для кожної точки значної просторової області (включаючи побудову профілю рельєфу до кожної точки та визначення множника ослаблення при інтерференції та рефракції), а отже великих обчислювальних витрат.

В умовах сучасних бойових дій за великої кількості РЕ3, оцінювання можливостей $з$ подавлення може здійснюватись лише заздалегідь та для фіксованих варіантів розташування РЕЗ та засобів РЕБ. Оперативне реагування на зміну радіоелектронної обстановки вбачається досить складним. Для зменшення об'єму обчислювальних витрат слід в виразах (1) та (2) виділити складову, яка описує умови роз- повсюдження електромагнітних хвиль та оцінити можливість та доцільність створення відповідного інформаційного шару геоінформаційної системи.

Множник

$$
\begin{gathered}
K_{\text {ГІС }}\left(r, \phi, h_{1}, h_{2}\right)= \\
=\frac{10^{0,1 V_{i}^{*}\left(r, \phi, h_{1}, h_{2}\right)} 10_{p}^{0,1 V_{p}^{*}\left(r, \phi, h_{1}, h_{2}\right)} e^{-\alpha r}}{r^{2}}
\end{gathered}
$$

описує вплив умов розповсюдження електромагнітної хвилі від точки знаходження постановника перешкод до точки з полярними координатами $r, \phi$.

При цьому значення коефіцієнта ослаблення в (2) визначають з виразу:

$$
K_{o c}=\left\{\begin{array}{l}
K_{\text {ГІС }}\left(r, \phi, h_{1}, h_{2}\right)^{\sqrt{\lambda}} \\
K_{\text {ГІС }}\left(r, \phi, h_{1}, h_{2}\right) \frac{1}{\sqrt{\lambda}}
\end{array}\right.
$$

для істотного впливу явища рефракції та для істотного впливу явища інтерференції відповідно.

Слід зауважити, що реалізація виразу (13) у вигляді шару ГІС передбачає зберігання великого об'єму даних і потребує застосування клієнтсерверної технології.

Для раціоналізації об'єму даних доцільно ввести обмеження та припущення, за яких використовуватиметься наведений математичний апарат при створенні спеціалізованої ГІС.

За умови $k=0,5$ з виразу (9) отримаємо розмір області простору, для якої слід враховувати вплив явища інтерференції:

$$
\left\{\begin{array}{l}
D=2 R_{1}=2 \sqrt{2 R_{3}\left(\frac{h_{1}+l_{1}+h_{2}+l_{2}}{2}-h_{i}\right)}, \\
\text { якщзо } \frac{h_{1}+l_{1}+h_{2}+l_{2}}{2}-h_{i}>0 \\
D=0, \text { якщо } \frac{h_{1}+l_{1}+h_{2}+l_{2}}{2}-h_{i} \leq 0 .
\end{array}\right.
$$

та з виразу (12) - явища рефракції:

$$
\left\{\begin{array}{l}
D=2 R_{1}=2 \lambda\left(\frac{h_{p 0}-0,5\left(l_{1}+h_{1}+l_{2}+h_{2}\right)}{0,8}\right)^{2}, \\
\text { якщцо } h_{p 0}-0,5\left(l_{1}+h_{1}+l_{2}+h_{2}\right)>0 ; \\
D=0, \text { якщзо } h_{p 0}-0,5\left(l_{1}+h_{1}+l_{2}+h_{2}\right) \leq 0 .
\end{array}\right.
$$

Проведемо практичні розрахунки для отримання орієнтовних значень на пропонуємому шарі ГІС, з метою оцінки можливості застосування запропонованого математичного апарату.

За висоти антени 20 м для нерівномірності рельєфу $10 \%$ область простору, на якій слід врахову- 
вати явище інтерференції, обмежується радіусом 1,5 км. Для дискретності значень висот антен 1 м, координат дальності $100 \mathrm{M}$, координат азимуту $1^{\circ}$ об'єм даних являтиме масив розмірністю $20 \times 20 \times 15 \times 360$ та міститиме 2160000 значень. Така кількість значень отримана для площі $S=\pi r^{2}=3,14 \times 1,5^{2}=7,065 \mathrm{~km}^{2}$. Тоді кількість значень на кожний км² буде складати 305732. Якщо кожне значення множника ослаблення має розмір 1 байт, то для зберігання інформації масиву коефіцієнтів ослаблення для кожної точки простору потребує 300кб (305732 : 1024) інформації.

\section{Висновки}

У статті запропоновано підхід для побудови спеціалізованого шару параметрів рельєфу місцевості у геоінформаційній системі для планування дій PE3 в умовах РЕБ завдяки урахуванню параметрів впливу умов поширення електромагнітних хвиль (рельєфу місцевості) 3 подальшою метою збільшення ефективності радіоелектронного подавлення через визначення співвідношень енергетики сигналів та перешкод у будь-якій точці простору за значеннями характеристик передавача та приймача сигналів, а також засобу перешкод.

Врахування умов розповсюдження електромагнітних хвиль, наведених у статті, здійснюється на основі попередньо розрахованої для кожної пари точок матриці коефіцієнтів згасання та реалізованої у вигляді спеціалізованого шару ГІС.

Запропоновано математичний апарат для розрахунків та визначено умови істотного впливу явищ інтерференції та рефракції, при цьому, ділянка простору, в межах якої розраховують коефіцієнти згасання, обмежується дальністю прямої видимості (з урахуванням можливих висот підйому антен та явища рефракціі).

Проведені практичні розрахунки для отримання орієнтовних значень, з метою оцінки можливості застосування запропонованого математичного апарату, показали несуперечність та теоретичну можливість його застосування у вигляді спеціалізованого шару ГIC.

Вказаний математичний апарат та підхід до його отримання може бути корисний як при вдосконаленні існуючих ГІС, так і при розробці нових спеціалізованих ГІС.

Реалізація пропонуємого шару у ГІС дозволить оперативно реагувати на зміни в радіоелектронній обстановці та розраховувати можливе радіоподавлення в реальному масштабі часу під час займання незапланових позицій РЕ3.

При проведенні подальших досліджень необхідно вирішити завдання оптимізації об’єму спеціалізованого шару ГІС та швидкісного доступу до даних, так можливості інтеграції до існуючих ГІС.

\section{Список літератури}

1. McDermott R.N. Russia's electronic warfare capabilities to 2025 [Electronic resource] / R.N. McDermott. - International center for defense and security. $\quad$ - 2017. $\quad$ - $48 \mathrm{p}$. $\quad$ Available at: https://icds.ee/wpcontent/uploads/2018/ICDS_Report_Russias_Electronic_Warfare_to_2025.pdf.

2. Алімпієв А.М. Особливості гібридної війни РФ проти України. Досвід, що отриманий Повітряними Силами Збройних Сил України / А.М. Алімпієв, Г.В. Пєвцов // Наука і техніка Повітряних Сил Збройних Сил України. - 2017. № 2(27). - C. 19-25. https://doi.org/10.30748/nitps.2017.27.03.

3. Ruifang, Ye. (2013), The future development of foreign military electronic warfare UAVs / Ye. Ruifang, Wu. Tanran, Ren Xian-gyu //Aerospace Electronic Warfare. - 2013. - Vol. 2. - P. 12-15.

4. Тенденции развития авиационных средств радиоэлектронной борьбы военно-воздушных сил Соединенных Штатов Америки / Я.Н. Кожушко, А.И. Резниченко, Ю.А. Олейник [та ін.] // Наука і техніка Повітряних Сил Збройних Сил України. - 2011. - № 2. - С. 44-48.

5. Ткачов В. Система обробки й доведення геопросторових даних до споживачів Сухопутних війск США / В. Ткачов // Закордонний військовий огляд. - 2007. - № 3. - С. 31-39.

6. NATO Standard AJP-3.17 Allied Joint Doctrine for geospatial support Edition A, Version 1 NSO, October 2016. - 34 p.

7. NATO Standard AJP-3.3. Allied Joint Doctrine for air and space operations. Edition B, Version 1. NSO, April 2016. $100 \mathrm{p}$.

8. Журавський Ю.В. Оцінювання ефективності радіоподавлення в умовах похибок визначення координат передавача сигналу / Ю.В. Журавський // Військово-технічний збірник Академії СВ імені гетьмана Петра Сагайдачного. Львів : АСВ, 2012. - № 7(2). - С. 63-68.

9. Журавський Ю.В. Оцінювання ефективності радіоподавлення систем радіозв'язку в умовах невизначеності координат приймачів / Ю. В. Журавський // Системи обробки інформації. - 2009. - № 2(76). - С. 45-47.

10. Журавський Ю.В. Оцінювання ефективності радіоелектронного подавлення в умовах похибок визначення координат передавача та приймача сигналу / Ю.В. Журавський, Ю.Г. Даник // Зб. наук. праць ВІТІ НТУУ КПІ. - К. : ВІТІ НТУУ КПІ, 2012. - № 2. - С. 44-49.

11. Журавський Ю. В. Методика побудови зони подавлення системи радіозв'язку з урахуванням рельєфу місцевості, сферичності Землі та тропосферної рефракції / Ю.В. Журавський, О.Л. Сидорчук // Труди академії. - 2008. - № 1(81). - C. 96-101. 
12. Кирилюк В.А. Критерій вибору дальності винесення станції перешкод відносно об'єкта, що прикривається / В.А. Кирилюк, О.Л. Сидорчук, О.С. Корняков // Проблеми створення, випробування, застосування та експлуатації складних інформаційних систем: зб. наук. пр. - Житомир: ЖВІ НАУ, 2010. - Спецвип. 1. - С. 13-21.

13. Кирилюк В.А. Критерій вибору позиції станції перешкод бортовим радіолокаційним станціям / В.А. Кирилюк // Труди університету: Зб. наук. праць. - Київ: НУОУ, 2011. - № 1(103). - С. 155-160.

14. Данилович О.С. Проектирование цифровых радиорелейных линий. Расчет показателей качества передачи / О.С. Данилович. - СПб.: Линк, 2009. - 76 с.

15. Данилович О.С. Сравнительный анализ методов оценки влияния интерференционных замираний на интервалах цифровых РРЛ/ О.С. Данилович, Н.Н. Бабин // Телекоммуникации. - Спец. выпуск. - 2013. - С. 34-46.

16. Бабин Н.Н. Оптимизация мощностей передатчиков и частотно-территориального планирования на сетях радиосвязи со звездообразной топологией / Н.Н. Бабин, Д.А. Данилович, О.С. Данилович // Известия вузов. Поволжский регион. Технические науки. - 2012. - № 4(24). - С. 67-75.

17. Антонов Л.А. Проверка допустимости пролетов и высот антенн на цифровых РРЛ ДМ диапазона / Л.А. Антонов, О.С. Данилович // Труды учебных заведений связи. - СПбГУТ. - 1997. - № 163. - С. 150-156.

18. Радзиевский В.Г. Современная радиоэлектронная борьба. Вопросы методологии / В.Г. Радзиевский, А.А. Агафонов. - М.: Радиотехника, 2006. - 424 с.

19. Калинин А.И. Распространение радиоволн и работа радиолиний / А.И. Калинин, Е.Л. Черенкова. - М.: Связь, 1971. $-439 \mathrm{c}$.

20. Корн Г. Справочник по математике для научных работников и инженеров / Г. Корн, Т. Корн. — М. : Наука, 1968. $-716 \mathrm{c}$.

\section{References}

1. McDermott, R.N. (2017), Russia's electronic warfare capabilities to 2025, International center for defense and security, 48 p., available at: https://icds.ee/wp-content/uploads/2018/ICDS_Report_Russias_Electronic_Warfare_to_2025.pdf.

2. Alimpiev, A. and Pevtsov, G. (2017), "Osoblyvosti gibrydnoyi vijny RF proty Ukrayiny. Dosvid, shho otrymanyj Povitryanymy Sylamy Zbrojnyx Syl Ukrayiny" [The features of the hybrid war of the Russian Federation against Ukraine. Experience received by the Air Forces of the Armed Forces of Ukraine], Science and Technology of the Air Force of Ukraine, No. 2, pp. 19-25. https://doi.org/10.30748/nitps.2017.27.03.

3. Ruifang, Ye., Tanran, Wu. and Xian-gyu, Ren (2013), The future development of foreign military electronic warfare UAVs, Aerospace Electronic Warfare, Vol. 2, pp. 12-15.

4. Kozhushko, Ya.M., Reznichenko, A.I., Oleinik, U.A. and Mykhailik, A.A. (2011), "Tendencyi razvitiya aviacionnyh sredstv radioelektronnoj borbi voenno-vozdushnyh sil Soedynennyh Shtatov Ameriki" [Progress of aviation tools of radioelectronic fight of air arms of the United States of America trends], Science and Technology of the Air Force of Ukraine, No. 2, pp. 44-48.

5. Tkachev, V. (2007), "Systema obrobky i dovedennya geoprostorovyh danyh do spozhyvachiv Suhoputnyh vijsk SShA" [The system of processing and proofing of geospatial data to consumers of the land forces of the USA], Foreign military review, No. 3, pp. 31-39.

6. NATO Standard AJP-3.17 (2016), Allied Joint Doctrine for geospatial support Edition A, Version 1, NSO, 34 p.

7. NATO Standard AJP-3.3 (2016), Allied Joint Doctrine for air and space operations. Edition B, Version 1, NSO, 100 p.

8. Zhuravs'kij, Ju.V. (2012), "Ocinjuvannja efektivnosti radiopodavlennja v umovah pohibok viznachennja koordinat peredavacha signalu" [Evaluation of radio suppression efficiency in terms of errors in determining the coordinates of the signal transmitter], Military Technical Collection of the Hetman Peter Sahaidachny Academy of Land Forces, No. 7, pp. 63-68.

9. Zhuravs'kij, Ju.V. (2009), “Ocinjuvannja efektivnosti radiopodavlennja sistem radiozv'jazku v umovah neviznachenosti koordinat prijmachiv" [Evaluation of radio suppression performance of radio systems in uncertainty of receiver coordinates], Information Processing Systems, No. 2(76), pp. 45-47.

10. Zhuravs'kij, Ju.V. and Danik, Ju.G. (2012), “Ocinjuvannja efektivnosti radioelektronnogo podavlennja v umovah pohibok viznachennja koordinat peredavacha ta prijmacha signalu" [Evaluation of the effectiveness of electronic suppression in the conditions of errors in determining the coordinates of the transmitter and receiver], Scientific Works of VITI NTUU KPI, No. 2, pp. 44-49.

11. Zhuravs'kij, Ju. V. and Sidorchuk, O.L. (2008), "Metodika pobudovi zoni podavlennja sistemi radiozv'jazku z urahuvannjam rel'efu miscevosti, sferichnosti Zemli ta troposfernoï refrakcii” [Methods of constructing a radio zone suppression zone taking into account the terrain, sphericity of the Earth and tropospheric refraction], Scientific Works of Academy, No. 1(81), pp. 96-101.

12. Kyryliuk, V.A., Sidorchuk, O.L. and Kornjakov, O.S. (2010), "Kriterij viboru dal'nosti vinesennja stanciï pereshkod vidnosno ob'ekta, shho prikrivaet'sja" [The criterion for choosing the range of an interference station with respect to a hiding object], Problems of creation, testing, application and operation of complex information systems, No. 1, pp. 13-21.

13. Kyryliuk, V.A. (2011), "Kriterij viboru poziciï stanciï pereshkod bortovim radiolokacijnim stancijam" [Criterion for selecting the position of an interference station for onboard radar stations], Scientific Works of Academy, No. 1(103), pp. 155-160.

14. Danilovich, O.S. (2009), "Proektirovanie cifrovyh radiorelejnyh linij. Raschet pokazatelej kachestva peredachi" [Design of digital radio relay lines. Calculation of transmission quality indicators], Sankt-Peterburg, $76 \mathrm{p}$. 
15. Danilovich, O.S. and Babin, N.N. (2013), "Sravnitel'nyj analiz metodov ocenki vlijanija interferencionnyh zamiranij na intervalah cifrovyh RRL" [Comparative analysis of methods for assessing the effect of interference fading on digital PLL intervals], Telecommunications, pp. 34-46.

16. Babin, N.N., Danilovich, D.A. and Danilovich, O.S. (2012), "Optimizacija moshhnostej peredatchikov i chastotnoterritorial'nogo planirovanija na setjah radiosvjazi so zvezdoobraznoj topologiej” [Optimization of transmitter capacities and frequency-territorial planning on radio communications networks with star topology], News of universities. Volga region. Engineering sciences, No. 4(24), pp. 67-75.

17. Antonov, L.A. and Danilovich, O.S. (1997), "Proverka dopustimosti proletov i vysot antenn na cifrovyh RRL DM diapazona" [Checking the permissibility of spans and antenna heights on DMR digital RRLs], Works of the educational institutions of communication, No. 163, pp. 150-156.

18. Radzievskij, V.G. and Agafonov, A.A. (2006), "Sovremennaja radiojelektronnaja bor'ba. Voprosy metodologii" [Modern electronic warfare. Methodology issues], Radio engineering, Moscow, $424 \mathrm{p}$.

19. Kalinin, A.I. and Cherenkova, E.L. (1971), "Rasprostranenie radiovoln i rabota radiolinij" [Propagation of radio waves and operation of radio lines], Communication, Moscow, $439 \mathrm{p}$.

20. Korn, G. and Korn, T. (1968), "Spravochnik po matematike dlja nauchnyh rabotnikov i inzhenerov" [Handbook of mathematics for researchers and engineers], Moscow, $716 \mathrm{p}$.

Надійшла до редколегії 28.04.2020

Схвалена до друку 09.06.2020

\section{Відомості про авторів:}

\section{Пічугін Михайло Федорович} кандидат військових наук професор провідний науковий співробітник Харківського національного університету Повітряних Сил ім. І. Кожедуба, Харків, Україна https://orcid.org/0000-0002-8012-7487

\section{Іщенко Дем`ян Андрійович}

кандидат технічних наук доцент старший науковий співробітник Житомирського військового інституту ім. С.П. Корольова,

Житомир, Україна

https://orcid. org/0000-0001-9743-3889

\section{Кирилюк Володимир Анатолійович}

кандидат технічних наук старший науковий співробітник начальник науково-дослідної лабораторії

Житомирського військового інституту

ім. С.П. Корольова,

Житомир, Україна

https://orcid.org/0000-0003-3184-7944

\section{Кожушко Ярослав Миколайович}

кандидат технічних наук

старший науковий співробітник

Харківського національного університету

Повітряних Сил ім. І. Кожедуба,

Харків, Україна

https://orcid.org/0000-0002-4229-6757

\section{Information about the authors:}

\author{
Mikhailo Pichugin \\ Candidate of Military Sciences Professor \\ Lead Research \\ of Ivan Kozhedub Kharkiv National \\ Air Force University, \\ Kharkiv, Ukraine \\ https://orcid.org/0000-0002-8012-7487
}

\author{
Dem'yan Ischenko \\ Senior Research Associate \\ of S.P. Korolyov \\ Zhitomyr military institute, \\ Zhitomyr, Ukraine \\ https://orcid. org/0000-0001-9743-3889
}

Candidate of Technical Sciences Associate Professor

\section{Volodymyr Kyryliuk}

Candidate of Technical Sciences Senior Research

Chief of Research Laboratory

of S.P. Korolyov

Zhitomyr military institute,

Zhitomyr, Ukraine

https://orcid.org/0000-0003-3184-7944

\section{Yaroslav Kozhushko}

Candidate of Technical Sciences

Senior Research Associate

of I. Kozhedub Kharkiv National

Air Forces University,

Kharkiv, Ukraine

https://orcid.org/0000-0002-4229-6757

\title{
ПОСТРОЕНИЕ СПЕЦИАЛИЗИРОВАННОГО СЛОЯ ПАРАМЕТРОВ РЕЛЬЕФА МЕСТНОСТИ В ГЕОИНФОРМАЦИОННОЙ СИСТЕМЕ ДЛЯ ПЛАНИРОВАНИЯ ДЕЙСТВИЙ РАДИОЭЛЕКТРОННЫХ СРЕДСТВ В УСЛОВИЯХ РАДИОЭЛЕКТРОННОЙ БОРЬБЫ
}

\author{
М.Ф. Пичугин, Д.А. Ищенко, В.А. Кирилюк, Я.Н. Кожушко
}

\begin{abstract}
Предложен подход к учету влияния рельефа местности на радиоэлектронное подавление приемников радиоэлектронных объектов различного базирования за счет построения специализированного слоя геоинформационной системы. Подход предполагает создание для каждой точки карты массива коэффициентов затухания при распространении
\end{abstract}


электромагнитной волны к любой другой точке, заданной с определенной дискретностью в пределах ограниченного участка пространства. Обоснованы условия преобладающего влияния явлений интерференции и рефракции для превышений физических препятствий на трассе распространения электромагнитных волн. Приведены математический аппарат расчета радиоэлектронного подавления для формирования массива данных для специализированного слоя геоинформационной системы.

Ключевые слова: эффективность подавления, множитель ослабления, интерференция, рефракиия, условия распространения электромагнитных волн, геоинформационная система, радиоэлектронное средство.

\section{CONSTRUCTION OF A SPECIALIZED LAYER OF TERRAIN RELIEF PARAMETERS IN A GEOINFORMATION SYSTEM FOR PLANNING ACTIONS OF RADIO ELECTRONIC MEANS IN CONDITIONS OF ELECTRONIC WARFARE}

M. Pichugin, D. Ishchenko, V. Kyryliuk, Ya. Kozhushko

An approach is proposed to take into account the influence of the terrain on the electronic suppression of receivers of various electronic objects based on the construction of a specialized layer of a geographic information system. The approach involves the creation of an array of attenuation coefficients for each point of the map during the propagation of an electromagnetic wave to any other point specified with a certain discreteness within a limited area of space. The conditions of the predominant influence of the phenomena of interference and refraction for exceeding physical obstacles on the propagation path of electromagnetic waves are substantiated. The mathematical apparatus for calculating electronic suppression for the formation of a data array for a specialized layer of the geographic information system is presented.

In modern combat operations with a large number of radio electronic devices, the assessment of suppression capabilities can be carried out only in advance and for fixed options for the location of radio electronic equipment and electronic warfare. Responding promptly to changing the electronic environment seems to be quite complicated. Conducted practical calculations to obtain indicative values, in order to evaluate the possibility of using the proposed mathematical apparatus, showed the consistency and theoretical possibility of its application in the form of a specialized layer of geoinformation system.

This mathematical apparatus and the approach to its obtaining can be useful both in the improvement of existing geoinformation systems and in the development of new specialized geoinformation systems.

The implementation of the proposed layer in the geoinformation system will promptly respond to changes in the electronic environment and to calculate possible radio suppression in real time while occupying unplanned positions of electronic means.

Keywords: suppression efficiency, attenuation factor, interference, refraction, conditions for the propagation of electromagnetic waves, geographic information system, radio-electronic means. 